\title{
Pathological Interaction in Edward Albee's Who's Afraid of Virginia Woolf?
}

\author{
Samira Sasani \\ Department of Foreign Languages, Shiraz University, Shiraz, Iran
}

\begin{abstract}
Edward Albee's Who's afraid of Virginia Woolf? is the portrayal of one of the forms of entrapment in relationships, one of the forms of pathological interactions the anti-psychiatrists explore in their work. Studying this play, the reader asks himself, how come that two people who are quite nice when considered on their own can be such devils when put in each another's company? George and Martha are entrapped in their relationships and there is no vent out of it for them. The more they try to set themselves free the more the noose tightens and this is truly because of their pathological interaction. They are engulfed in an untenable situation since once a person entrapped in it he should choose between "badness" and "madness" which seem to be the only explanation and whatever he chooses is a failure for him. Employing communication theory, this study tries to investigate George and Martha's pathological interaction and the game of collusion they play upon their guests.
\end{abstract}

Index Terms-Edward Albee, Who's Afraid of Virginia Woolf?, paradoxical interaction, collusion, spiral perspective

\section{INTRODUCTION}

Games of deceit and betrayal are very much seen in the plays of modern dramatists. In other words, modern plays, especially those which are considered as family plays are about different forms of pathological relationships, deceitful games and frauds between a husband and a wife, or generally speaking, the members of a family. Pinter's plays, such as Caretaker, Betrayal and The Birthday Party; Tennessee Williams's A Streetcar Named Desire; Eugene O'Neill's Long Day's Journey into Night, and Recklessness; Lars Noren's Silance, to name a few, are all portraying different forms of entrapment in pathological relationships. Investigating these forms of pathological interactions is at the center of attention of anti-psychiatrists, such as Watzlawick, Laing, Phillipson, Lee, Bavelas, and Jackson.

Watzlawick's Pragmatics of Human Communication: A Study of Interactional Patterns, Pathologies, and Paradoxes is the study of pragmatic effects of human communication, in which disturbed behavior is seen as a communicative reaction to a particular situation rather than the evidence of the disease of an individual mind. Communication theory is concerned with the reactions of an individual to the reactions of other individuals and is liable to alter from time to time, even without disturbance from outside. Gregory Bateson defines communication as "the study of the reactions of individuals to the reactions of other individuals" while we should observe "not only A's reactions to B's behavior, but we must go on to consider how these affect B's later behavior and the effect of this on A" (qtd. in Watzlawick, 1967, P.153).

Watzlawick categorizes all communications into three groups: symmetrical, complementary and metacomplementary. Based on his definitions, complementary pattern of interaction is the pattern employed by Martha and George. In this kind of interaction, one partner may occupy the position of the superior, primary or "one-up" position, and consequently the other occupies the inferior, the secondary or "one-down" position (Watzlawick, 1967, P.69). In Laing's view, in complementary relationships "collusion" is at the center and we observe a growing sense of frustration and despair in one or both partners. Delusion, as Laing says, implies total self-deception; illusion implies a capacity to deceive oneself under a strong wish, but does not involve as total as self-deception as delusion. Collusion is a "game" played by two or more people whereby they deceive themselves. It is a game involving mutual self-deception. So collusion is necessarily a trans-personal or interpersonal process (self and others: Sanity and madness, 1961, P. 98). Roudane suggests that Who's Afraid of Virginia Woolf? Just says have your pipe-dreams if you want to but realize you are kidding yourself" (2006, P.109), Roudane is right but Who's Afraid of Virginia Woolf? is more than just self-deception, it is a game of collusion as well.

Complaints of increasingly frightening feelings of self-estrangement and depersonalization are very frequently voiced by the individuals entrapped in collusion. They are perfectly capable of functioning satisfactorily when they are considered on their own but this picture often changes dramatically when these individuals are put in each other's company and when they are seen together with their "complements" (Watzlawick, 1967, P.109). They can become such devils when they are put in each other's company and the pathology of their relationship becomes patent.

Price believes that "Albee presents relationships in general and marriage in particular in terms of self-conscious, theatrical game playing in Who's afraid of Virginia Woolf?" (2007, P.257). What Price says is right but what Albee demonstrates in his play is not only a theatrical game playing but also a game-like interaction between four real 
characters. In other words, it is not just theatrical, since it can happen in everyday life between two people who are interacting as devils when they are in each other's company while they are quite nice when they are considered on their own. Cohn stipulates that all the games included in this play "-Humiliate the Host, Get the Guests, Hump the hostess, and Bringing up Baby_suggest a miniature society" (2006, P.96). Toby Zinman argues that in Who's Afraid of Virginia Woolf?, the plot shows "the dysfunctional family, a subject American drama has been in love with from the beginning" (2008, P.39).

\section{DISCUSSION}

George, Martha, Nick and Honey are the four people running the game of deceit in Albee's Who's Afraid of Virginia Woolf? It is midnight, two o'clock in the morning, George and Martha have already come back from the ceremony held in the house of Martha's father who is the professor and headmaster of the department in which George and Nick are teaching as university professors. Martha has invited a young couple, Nick and Honey, with whom she has newly got acquainted. Pathological communication between George and Martha starts from the very beginning, even before the arrival of the two other prominent characters who augment the complexity and complication of the pathological relationships occurring in this play.

George and Martha are intermittently kind and cruel towards each other. Their love-hate relationship is truly the cause of their deceitful game without end, and their pathological relationship from which there is no vent out. From the very beginning of the play, Martha is introduced as a headstrong character running her deceitful games with her reckless and indifferent attitude towards her husband, George, and his desires. Before the arrival of their guests, George objects to Martha: "I wish you'd tell me about something sometime. ... I wish you'd stop springing things on me all the time." (Albee, 1963, p. 11) However, Martha enjoys George's anger; she says: "I like your anger. I think that's what I like about you most ... your anger." (Albee, 1963, p.14) Very trivial things can be the subject of their quarrel. They eagerly start quarreling with each other and each thinks that he is the winner of the game he plays. The first game of power starts with Martha's mentioning of her teeth which are more than George's. George, in return, reminds her that he is six years younger than her:

George: I suppose it's pretty remarkable ... considering how old you are.

Martha: YOU CUT THAT OUT! (Pause) You are not so young yourself.

George: I'm six years younger than you are ... I always have been and I always will be. (Albee, 1963, p.15)

The prominent subject of their quarrel turns round having a son which they have promised to keep secret. While the guests are behind the door, George constantly pleads Martha not to mention their son:

George: Just don't start in on the bit about the kid, that's all.

Martha: What do you take me for?

George: Much too much.

Martha (Really angered): Yeah? Well, I'll start in on the kid if I want to.

George: Just leave the kid out of this.

Martha (Threatening): He's mine as much as he is yours. I'll talk about him if I want to.

George: I'd advise against it, Martha. (Albee, 1963, p.18-19)

Martha is obstinate and thinks that she knows how to run the game against George; she thinks she is the manipulator of the game and can make barehanded George angry and wins the power game. George also thinks that he knows what she thinks and thinks that he is the manipulator of the game. Moreover, throughout the play, they are ostensibly playing in one team in the presence of "others", of their guests. Thus, two prominent games are running throughout the play. One between Martha and George and the other one is ostensibly between Nick and Martha, playing in one team and George and Honey, playing in the other. Very much like their love-hate relationship both George and Martha are playing for and against each other; sometimes in one team and sometimes in different teams against each other. The pathological relationship between these two people is a game without end. An example, given by Laing, may clarify this situation:

This is how many people describe their experience of being unable to leave 'home', or the original other or nexus of persons in their life. They feel that their mother or family is smothering them. They are frightened and want to run away. But the more frightened they are, the more frightened and frightening their family becomes. They cling for security to what frightens them, like someone with a hand on a hot plate who presses his hand harder against it instead of drawing it away; or like someone, who begins to step on a bus just when it begins to move away and 'instinctively' clutches the bus, the nearest and most dangerous object, although the 'sensible' thing to do is to let go. (Selected Works, 2002, p.130)

While Nick and Honey, a young couple, come to their house and Martha wants to show Honey the house, George reads Martha's mind and is worried about what she will say to Honey. He guesses that Martha will reveal the secret to Honey and will break the rule of their game:

Martha: Honestly, George, you burn me up!

George (Happily): All right.

Martha: You really do, George.

George: O.K Martha ... O.K. just ... trot along.

Martha: You really do. 
George: Just don't shoot your mouth off ... about ... you know.

Martha (Surprisingly vehement): I'll talk about any goddamn thing I want to, George! (Albee, 1963, p.29)

The game Martha and George play before Nick and Honey, the third party, are very much reminiscent of the game Aston and Mick play with their uninvited guest, Davies in Harold Pinter's Caretaker. Nick, at first, estimates that George is tantalizing him, so he avoids taking part in any discussion with George. Unaware of George's collusion with Martha and the vortex in which he is assumed to plunge, Nick dodges George's questions. But even Nick's verbal refusal to take part in discussion with George paves the way for George to engage Nick in his indispensable game; though Nick is completely unaware of his tricky plot:

George: Don't you condescend to me! (Toying with him) I asked you how you liked that for declension: Good; better; best; bested. Hm? Well?

Nick (With some distaste): I really don't know what to say.

George (Feigned incredulousness): You really don't know what to say?

Nick (Snapping it out): All right ... what do you want me to say? Do you want me to say it's funny, so you can contradict me and say it's sad? Or do you want me to say it's sad and so you can turn around and say no, it's funny. You can play that damn little game any way you want to, you know!

George (Feigned awe): Very good! Very good!? (Albee, 1963, p.33)

Then George continues:

George: Well, now ... let's sit down and talk, hunh?

Nick (Cool again): It's just that I don't like to ... become involved ... (An afterthought) uh ... in other people's affairs. (Albee, 1963, p.34)

George's attempts to involve Nick in his game is fruitful to the extent that when George asks him whether Nick and Honey have a son or not, Nick simply responds him and tells him "No", but when Nick asks George the same question in return, George cunningly says: "That's for me to know and you to find out." (Albee, 1963, p.39) While involving Nick in his game, George is also worried about another game, about his game with Martha. Like a chess game, his game is a game of reading his rival's thoughts. It is a game of deceits, frauds, hoaxes, and generally speaking departure from reality; it is the game of pretension, insincerity, and from the view point of communication theory, a game of 'spiral perspectives' which is the cause of all these befuddlements and entrapments. Laing proposes a very concise formula of Spiral Interpersonal Perception: (Self and Others, 2002, p.99)
$\mathrm{A}(\mathrm{B})$
$\mathrm{A}(\mathrm{B}(\mathrm{A}))$
how A sees B
$\mathrm{A}(\mathrm{B}(\mathrm{A}(\mathrm{B})))$
how A sees B seeing A
how A sees B seeing A seeing B

The algorithm is useful; it helps a spectator achieve a basic understanding of deceiving games the characters play against one another in the spiral interpersonal perception. Luc Gilleman also believes that this pattern, proposed by Laing, of interaction results in a "vortex" or system of interlocking spiral perspectives" (2008, p.83).

Paradoxically, the characters' very attempts at creating clarity lead to increased confusion. George moves his pawns the way that he can estimate what his rival's movement will be in return. In other words, he cunningly stimulates Nick and Martha and then dexterously planned his reaction; however, Nick and Martha still think that they are manipulating the game. George is one level ahead; he is in one-up position, though Nick and Martha mistakenly consider themselves as the wiser part of the game.

George is able to read her wife's mind and knows what she thinks and what her next movement will be in their game. While Honey and Martha are upstairs, George expresses his anxiety about what is happening upstairs between these two women; he tells Nick: "One of the things I do not know about them is what they talk about while the men are talking. (Vaguely) I must find out some time." (Albee, 1963, p.42) George has estimated that Martha has broken the rule of their game deliberately to make him angry and wins the game. George is right; Honey reveals to George that Martha has told her about their son. Hearing this from Honey's mouth, George, as the stage direction reads, wheels "as if stuck from behind" (Albee, 1963, P.44). He has verified his estimations and now he is ensured that he knows what Martha and Nick think about him and what they will do.

Martha who mistakenly thinks that it is she who manipulates the game tries to engage Honey in a game of frauds and deceits of a wife and a husband. But she is not that much successful; she is not as successful as George is. Martha can engage Honey a little bit in the game when Honey is deceived and reveals the secret of her marriage with Nick to Martha. Every part and parcel of Who's Afraid of Virginia Wools? is a game embedded in the two prominent aforementioned games played mainly by George and Martha. This play is replete with pretentions, deceits, collusions, and vortexes that all of the people in the play are entrapped in; in other words they are all entrapped in a pathological relationship from which there is no vent out. The more they try to set themselves free, the more the noose tightens.

The story Martha tells to Nick about George's game of boxing is very telling of the pattern of the game which is in her mind and the way she is playing with George. She knows that George is very much concerned about his muscles, and his body, so she puts forward the story of his defeat in boxing and the way she deceives him and makes him defeated and hit by his rival. She believes: "I think it's colored our whole life." (Albee, 1963, p.57) She knows that telling this story will surely make George mad and this is what she desires. George in return, takes from behind his back a short-barreled shotgun and calmly aims it at the back of Martha's head and pulls the trigger. "You are dead! Pow! You 
are dead!" George says (Albee, 1963, p.57). Though from the barrel of the gun blossoms a large red and yellow Chinese parasol, what George does symbolically foreshadows Martha's defeat in the pathological game of power running between this couple.

The pathological relationship between George and Martha extends to other relationships as well. Collusion is at the heart of all relationships in this paly. Who's afraid of Virginia Woolf? is divided into three parts; the name of each part is truly very telling of what is happening in that act of the play. The first part called "Fun and Games", not only portrays the game between George and Martha but also the game they establish to involve the young couple especially Nick who erroneously thinks he is so wise that he is not engulfed in the pathological relations of Martha and George. George, in the first act, reminds Martha to start blue games for the guests:

George: Oh-ho! That's what you're after, is it? What are we going to have ... blue games for the guests? Hunh? Hunh? Martha (Angry-hurt): You ... prick!

George (A pyrrhic victory): Everything in its place, Martha ... everything in its own good time. (Albee, 1963, p.59)

The way George and Martha behave the guests is very much like the way Mick and Aston treat Davies, in Caretaker. Nick, very much like Davies, is entrapped in a game of which he is unaware. He really thinks that he knows what George and Martha think, but he really is unaware of their plan. Ostensibly, George and Martha are fighting against each other but it is just the veneer of the matter. He does not know, though he mistakenly thinks he knows, that he is a puppet in the hands of George and Martha. As the surface structure of the game represents, Nick thinks that the more powerful person in this game is Martha, so Nick takes side with Martha, very much like Davies who takes side with Mick against Aston. In "Fun and Games", Martha and George decide to entertain their guests by entrapping them in their pathological relationships.

A kind of Strindbergian quarrel between George and Martha makes Honey mad and makes Nick a bad character who at the end of the game or the play, very much like Davies, understand the true nature of the game they are engulfed in. When Honey asks George to talk about their twenty-one year old son, George asks Martha to talk about this subject since it was she who brought the secret up, so she is the one who should take the responsibility of talking about the forbidden matter, their son. On the other hand Martha tries to change the subject to an issue which is disgusting for George, to the extent that it makes George mad or sad. Very much like Strindberg's The Father, Martha -like the captain's wife, Laura - tells the guests: "George's biggest problem about the little ... ha, ha, ha, ha! About our son, about our great big son, is that deep down in the private-most pit of his gut, he's not completely sure it's his own kid." (Albee, 1963, p. 71) Unlike Captain in The Father, George is the stronger and wiser person in the deceitful game; he not only does not doubt about his fatherhood, but he also shifts the fraudulent plan towards Martha and introduces her as the liar.

The pathological interactions these people are entrapped in lead them to badness or madness. A person caught in paradoxical injunction or double bind is in untenable position from which his chance of stepping outside is very slim. Watzlawick suggests different examples to clarify this situation which ultimately leads to the untenable situation no one wants to be engulfed in. This situation is called untenable, since a person entrapped in it should choose between "badness" and "madness" which seem to be the only explanation and whatever he chose is a failure for him. Thus, he gets befuddled and cannot solve this very complicated problem (1967, pp.212-13).

Actually, the pathological game is a game without end and nothing from within can change this relationship, these people are hopelessly entrapped in it and the only remedy is the death of one of the partners of the interaction. By mentioning the secret, the son, Martha tries to make George mad. On the other hand, George breaks a bottle to intimidate Martha and control her game; in other words to defeat her by making her a mad or a bad character. The first act of the play ends while George and Martha have established their fraudulent game to which the guests are introduced and also somehow enmeshed in while they really do not want to.

George, Martha, Nick and Honey's pathological interactions are significantly exposed in the second act. They are entangled more in the net of pathological relationships and the noose tightens more in the second act of the play. Though Nick again, in this act, insists that he does not want to be engaged in the interaction between George and Martha, he unknowingly gets involved much more than the previous act in the pathological relationships between the couple. George tells Nick a story of a fifteen-year-old boy who killed his mother with a shotgun completely accidentally, "without even an unconscious motivation, I have no doubt, no doubt at all" (Albee, 1963, p. 94) and who killed his father in a car accident when he swerved the car, to avoid a porcupine, and drove straight into a large tree. This storyin the hands of these people - in different colors and forms, is a tool for deceiving and bothering one another. Schechner believes that " there is no real, hard bedrock of suffering in Virginia Woolf-it is all illusory, depending upon a "child" who never was born: a gimmick, a trick, a trap" (2006, p.77).

Nick is entrapped in a pathological game to the extent that he tells George about the secret of his marriage with Honey, about her sickness, pregnancy and even about his father-in-law. Nick is still completely unaware of his entrapment in the game, though George tries to let him know that he is entrapped. George in the beginning of the second act, the act of the peak of deceits and frauds, advices Nick, though Nick laughs at him, belittles him and does not consider him serious:

George (Like a father): I wish I were ... I'll give you some good advice if you want me to ...

Nick: Good advice! From you? Oh boy! (Starts to laugh) 
George: There's quicksand here, and you'll be dragged down, just as ...

Nick: Oh boy ...!

George: ... before you know it ... sucked down ...

(Nick laughs derisively)

You disgust me on principle, and you're a smug son of a bitch personally, but I'm trying to give you a survival kit. DO YOU HEAR ME? (Albee, 1963, p.115)

Reckless to George's admonition, Nick plunges into a game of deceit running between George and Martha. George accuses Martha of making Honey sick; she, in return, accuses Martha of making their son sick. They call each other liar; Martha puts forward the problematic issue, the story of killing a father and a mother but this time in the form of a novel written by George. Another secret is revealed by Martha. Martha carries out the game well. George tries to stop the game, but the relationship is pathological, the more they try to set themselves free, the more the noose tightens. George decides to retaliate to stop her. "George and Martha are attuned to one another, and they need one another" (Cohn 91). George tells Martha: " It's just I've got to figure out some new way to fight you, Martha. Guerilla tactics, maybe ... internal subversion ... I don't know. Something." (Albee, 1963, p.125) As Watzlawick believes nothing from within can stop the game. It is a game without end and the only remedy is death of one of the partners.

While dancing with Nick, Martha brings up the story of George's novel again to arouse Nick and engage him in their game. She knows how to arouse George's anger and how to carry out the game. George warns Martha that "THE GAME IS OVER" (Albee, 1963, p. 136), but Martha heedlessly continues and tells Nick and Honey: "Imagine such a thing! A book about a boy who murders his mother and kills his father, and pretends it's all an accident!" (Albee, 1963, p. 136). George is wiser than Martha. She does not know that she is not the one manipulating the game but it is George. She does not know George's rules, so she is defeated by him physically and mentally several times. He plans another game in which Martha, Nick and Honey are the puppets while all of them are unaware of it.

George addresses Martha as "book dropper! Child mentioner!" (Albee, 1963, p.140); he retaliates by proposing a new game which he has fabricated. "We've played Humiliate the Host ... we've gone through that one ... what shall we do now?" (Albee, 1963, p.138); "there are other games. How about ... how about ... Hump the Hostess?" (Albee, 1963, p.139). Martha mistakenly addresses him as "a portrait of a man drowning"; she does not know that it is she who is drowning; even in a game called "Humiliate the Host", she was the loser not George; since she could not wisely manage "Humiliate the Host", it reversely paves the way for her defeat. When George sees that none of them are satisfied whit his suggestion, he changes the game and proposes: "We'll play a round of Get the Guests. How about that? How about a little game of get the guests?" (Albee, 1963, p.140). George knows what he is doing and knows how to control Martha, Nick and Honey. Any of these games proposed by George well corresponds to his purpose: the entrapment of both Nick and Martha in his game.

Since he is annoyed by Martha's mentioning of the story of his novel, he, as the wiser partner of the game, who is in one-up position and who can read his rival's mind tries another plot. George mischievously asks Martha if she has told the guests about his second novel. Honey who has been very little entrapped in their interactions, enthusiastically asks George to tell them his story while she is unaware of George's plan. Hearing George's second novel, Honey understands that the secret of her marriage with Nick has been revealed to George by Nick. A young couple's quarrel, Honey and Nick, indicates how much George has been successful in engaging the guests, the third party, in his pathological interaction with Martha. All of them are deceiving and betraying one another. No one can trust the other one. It is like a chess game full of fraud and deception. George is on one side of a chess game and the three other characters who are manipulated by him are on the other side. George says: "this is my game! You played yours ... you people. This is my game!" (Albee, 1963, p.142). Even Martha who ostensibly plays in the same team with Nick, is not honest with Nick and is the accomplice of George, deceives him and plays an important role in the game of "Get the Guests" fabricated and proposed by her husband, George, against Nick and Honey.

Seeing Nick and Honey struggling in a net to make themselves free, George becomes sure that his game runs well and it is still controlled by him. Abruptly and with some disgust, as the stage direction reads, George states: "and that's how you play Get the Guests" (Albee, 1963, p.148). George advices Nick pick up the damaged pieces and plan some new strategy. Nick who anxiously finds himself in the trap and can find no way to get out of it, decides to take revenge, but what is ridiculous is that he does not understand it from the very beginning though George did warn him of what was happening to him. Both Martha and George deceive Nick and Nick very simply takes Martha's side; he thinks that he is playing in one team with Martha. Completely unaware of this fact that no two people are playing in one team in this game set by George and Martha. Nick intimidates George:

Nick: I'll play the charades like you 've got 'em sset up ... I'll play in your language ... I'll be what you say I am.

George: you are already ... you just don't know it.

Nick (shaking within): No ... no. not really. But I'll be it, mister ... I'll show you something come to life you'll wish you hadn't set up. (Albee, 1963, p.150)

Nick is befuddled, shakes within, and now understands that he is engulfed in a game which is like the charades. $\mathrm{He}$ relied on George and very dexterously he was entrapped; now he understands that he is mistaken but he again trusts Martha another partner of the game of deception. While Nick is struggling in their trap, George smiles at Martha and both thank each other for artistically carrying out the plan: 
Martha: Very good George.

George: Thank you, Martha.

Martha: Really good.

George: I'm glad you liked it.

Martha: I mean ... you did a good job ... you really fixed it.

George: You bring out the best in me, baby. (Albee, 1963, p.151)

But appreciation does not last much and syncopation happens again here. The love-hate relationship between this couple shows itself very sharply here when Martha in reaction to George's thanks and admiration, surprisingly, calls him miserable, a bastard, the one who makes her sick. The paradoxical reaction is not limited to Martha, George also behaves paradoxically. He tells Martha that what he does is just for her; "I thought you'd like it, sweetheart ... it's sort of to your taste ... blood, carnage and all. Why, I thought you'd get all excited" George says (Albee, 1963, p. 152). On the other hand, very cunningly, he suggests Martha that she make her own rules if she cannot stand his. He complains that he cannot stand her behavior when she tears him apart all the time, but Martha believes that he can stand it sine he married her for it. Watzlawick stipulates that there is something in the nature of paradox which makes it pragmatically and existentially crucial in the relationships. "Paradox not only can invade interaction and affect our behavior and our sanity, but also it challenges our belief in the consistency, and therefore the ultimate soundness of our universe" (1967, p.187).

George - as he warned Nick, before - warns Martha that she is getting mad and is deluded, but Martha, very much like Nick, thinks that she is the manipulator, thus she carries on the game. The quarrel between George and Martha, the schizophrenic people, never ends and none of them can stop the game. Based on Laing's theory, people engulfed in schizophrenic interactions are constantly puzzling over what is meant by any statement, for any statement can function in innumerable ways (Self and Others: Sanity and Madness, 1961, p.158). The following is a model of their pathological interaction leading nowhere. It is one of the examples of the vicious circle they are engulfed in. They both desire to stop it, to get rid of it, but there is no way out it:

Martha: my arm has gotten tired whipping you.

George (stares at her in disbelief): You're mad.

Martha: For twenty-three years!

George: You're deluded ... Martha, you're deluded.

Martha: It's not what I've wanted.

George: I thought at least you were ... on to yourself. I didn't know. I ... didn't know.

Martha (Anger taking over): I'm on to myself.

George (As if she were some sort of bug): No ... no ... you're sick.

Martha (Rises—-screams): I'LL SHOW YOU WHO'S SICK!

George: All right, Martha ... you're going too far.

Martha (Screams again): I'LL SHOW YOU WHO'S SICK. I'LL SHOW YOU.

George (He shakes her): Stop it! (Pushes her back in her chair) Now, stop it!

...

George (Emphasizing with his forefinger): And you'll wish you'd never mentioned our son!

Martha (Dripping contempt): You ...

George: Now, I said I warned you.

Martha: I'm impressed.

George: I warned you not to go too far.

Martha: I'm just beginning. (Albee, 1963, pp.154-55)

Thus, after so much quarrel and argument, the game starts from the very beginning by Martha, "I'm just beginning". George also announces: "you try it and I'll beat you at your own game" (Albee, 1963, p. 158). Therefore, as both George and Martha mention, the total war begin again; in other words, they are much more entrapped and they plunge deeper into the ocean of deception. As George tells Martha: "we get misunderstood" (Albee, 1963, p.157) and "there is no moment any more when we could ... come together" (Albee, 1963, p.158). There is actually no moment any more when they could get out of the pathological game and quarrels.

Martha now tries to hurt George by engaging Nick, who takes side with her, in her game against George. Nick is again a puppet controlled completely by Martha. Like the first act of the play when she was somehow successful to make George sad and angry - though she was eventually defeated and beaten by George - she guesses that she would make George angry by necking with Nick. Several times she tells George what she is doing but George, who is busy reading a book, deliberately reacts calmly. However, George tells Martha quietly as if she were in the room: "I'm going to get you, Martha" (Albee, 1963, p.175). George is one step ahead while Martha is unaware of it. She leaves the room with Nick, George and Martha are with each other. George plans another game for Martha. George tells Honey that their son is dead and asks her not to let Martha know about it.

Honey, who is alone with George now, is not that much entrapped in George's plot. Actually what differs Honey from three other people of the ply is that she does not want to know anything and she has no claim of controlling and manipulating the game. When George asks him whether she knows what is going on there, she simply says: "I don't 
want to know anything." (Albee, 1963, p.178) The second act ends while an idea triggers in George's mind. He happily cries out: "I'VE GOT IT! I'VE GOT IT, MARTHA ...!" (Albee, 1963, p.180). George happily talks to himself:

Good ... good ... you go right ahead.

(Very softly, so Martha could not possibly hear)

Martha? Martha? I have some ... terrible news for you.

(There is a strange half-smile on his lips)

It's about our ... son. He's dead. Can you hear me, Martha? Our boy is dead.

(He begins to laugh, very softly ... it is mixed with crying). (Albee, 1963, p.181)

The name of the third act, "The Exorcism", very aptly foreshadows what is going to happen. As the title symbolically shows, it is supposed that the third act unfolds the essence of the whole play. The happenings of this act symbolically unfold the true nature of the pathological interactions. The third act, "The Exorcism", begins while Martha is talking to herself. She confesses her defeat to herself. She is reviewing with herself the cause of her failure. She acknowledges: "Martha, I've misjudged you. And I've misjudged you, too, George." (Albee, 1963, p.185) She also symbolically points to the game they played, the game without end:

I cry all the time. And George cries all the time, too. We both cry all the time, and then, what we do, we cry, and we take our tears, and we put 'em in the ice box, in the goddamn ice trays (Begins to laugh) until they're all frozen (Laughs even more) and then ... we put them ... in our drinks. (Albee, 1963, pp.185-6)

They cry and make the tears frozen and then they drink the tears and this cycle continues very much like the cycle of their pathological interactions which never ends. Nick also acknowledges that Honey "is lying down on the floor again, the tiles, all cured up, and she starts peeling the label off the liquor bottle, the brandy bottle" (Albee, 1963, p.187). It is as if everything is coming up to the surface, is peeled off and revealed truly as it is. Nick calls Martha and George crazy; Martha unfolds the cause of their madness and asserts that "'tis the refuge we take when the unreality of the world weighs too heavy on our tiny heads. Relax; sink into it; you're no better than anybody else" (Albee, 1963, p.188).

Martha calls Nick a flop as she calls George. Then she, surprisingly, appreciates her husband, "the only one man in my life who has ever ... made me happy" (Albee, 1963, p. 189). She believes that it is George "who keeps learning the games we play as quickly as I can change the rules; who can make me happy and I do not wish to be happy, and yes I do wish to be happy. George and Martha, sad, sad, sad." (Albee, 1963, p. 191) Martha accuses Nick of being seduced by appearances for one of the people who has deceived Nick is herself. Martha's paradoxical attitude towards George makes Nick very much puzzled. Nick unbelievingly echoes: "sad". Martha suddenly changes her attitude towards George whom she will not surprisingly forgive for having seen her, and as she says for "having said: yes; this will do; who has made the hideous, the insulting mistake of loving me and must be punished for it" and then she repeats herself : "George and Martha: sad, sad, sad." (Albee, 1963, p.191)

Nick again finds himself helplessly entrapped in a game this time manipulated by Martha. Nick is totally befuddled by paradoxical deeds and sayings of Martha. After her ambivalent attitude towards George, she starts taking paradoxically: "who tolerates, which is intolerable; who is kind, which is cruel; who is understands, which is beyond comprehension ...." (Albee, 1963, p. 191). She again accuses Nick of not seeing the realities. Nick is a scientist but cannot see the realities happening around him, she believes: "you see everything but the goddamn mind; you see all the little specs and crap, but you don't see what goes on, do you?" (Albee, 1963, p. 192). However, it is not just Nick's problem it is the problem of all the characters; Zinman asserts that "over and over George and Martha accuses each other of being unable to distinguish the facts from the fantasies of their lives, the most crucial of which is an imaginary child who has lives at the center of their marriage" (2008, p.41).

As George says, Nick is trapped in truth and illusion game. He cannot distinguish between truth and illusion. Consequently, he also entrapped in collusion. This is the problem of all the people of the play, however George is wiser and it is he who sets the rules of the power game and it is he who controls and manages the interactions, so he is the winner of the pathological game; he is the character who knows what other people think what he thinks. Nick, on the other hand, who does not want to get involved is so much entrapped that he has no other choice than being a mad or a bad character. He is the puppet not only in the hands of George but also in the hands of Martha. In "The Exorcism", when George and Martha play the last game of "bringing up baby", Nick much more understands the nature of the pathological game between Martha and George.

Despite Martha's persistent refusals, George brings up his last game called "bringing up baby". Like Nick who has two ways of getting out of the game, Martha has two ways as well, to become a mad or a bad character. And this is really what George wishes to accomplish his deceitful game; to make Martha mad or to defeat her as a bad or a weaker character. "Martha may have downed George with boxing-gloves, but he outpoints her with words" (Cohn, 2006, p. 91). The last game is like boxing for George:

George: pull yourself together! (Again) I want you on your feet and slugging, sweetheart, because I'm going to knock you around, and I want you up for it. (Again he pulls away, releases her; she rises)

Martha: All right, George, what do you want, George?

George: An equal battle, baby; that's all.

Martha: You'll get it!

Martha, the victim of these pathological interactions, approves her madness: 
George: I want you mad.

Martha: I'm mad!

George: Get madder!

Martha: DON'T WORRY ABOUT IT! (Albee, 1963, pp. 208-9)

George tackles the last game and asks everyone to take part in the last so-called "civilized game". He symbolically points to peeling the labels since this game is a game of "bringing up baby" embedded in a game of "The Exorcism". Actually all the characters try to lose the ties, though the more they try, the more the noose tightens. George the manipulator of the game symbolically refers to disclosing the secrets and rules of the games they played:" when you get through skin, all three layers, through the muscles, slosh aside the organs and get down to bone", "you haven't got all the way, yet. There's something inside the bone ... the marrow ... and that's what you gotta get at" (Albee, 1963, p. 213).

George and Martha are cooperating with each other to run the last game. Again Nick is the toy in their hands; again he takes side with Martha who is reluctant to perform the last game. George reminds Nick that he is not in a position to set the rules and again reminds all the people that it is he who runs the power game forward. He asks Martha to prepare the guests for the last game by reciting about her son. After her recitation they start quarreling with each other; they call themselves liars and they accuses each other of not paying enough attention to the son. George eventually reveals that their son is dead; he finally shoots the last bullet. The plot of his first novel incarnated in his last game and in the story of his son's death. The son, very much like the son of his novel, swerved to avoid a porcupine, and drove straight into a large tree. Martha cannot believe that George decides to run the game this way: "NO! NO! YOU CANOT DO THAT! YOU CAN'T DECIDE THAT FOR YOURSELF! I WILL NOT LET YOU DO THAT!", "I WILL NOT LET YOU DECIDE THESE THINGS" (Albee, 1963, p.232).

Nick is still involved in the pathological interaction between this couple. He tries to mitigate Martha: "He hasn't decided anything, lady. It's not his doing. He doesn't have the power" (Albee, 1963, p. 233). But Martha cannot believe that she has defeated by George, the thing Nick has not understood completely, yet. "YOU CAN'T KILL HIM! YOU CAN'T HAVE HIM DIE!" Martha told (Albee, 1963, p.233). Martha asks George to show her the death telegram, but George, exploding with laugher, acknowledges that he ate it. George also involves Honey in the game and asks her to testify that he ate the telegram and she does.

It is at the end of the play that both Nick and Martha understand the true nature of the relationship between George and Martha. The following conversation between George and Martha is worth mentioning since this conversation causes Honey and Nick understand the true nature of love-hate relationship, the power game, the pathological interaction between these two characters:

George (With disgust): YOU KNOW THE RULES, MARTHA! FOR CHRIST'S SAKE, YOU KNOW THE RULES! Martha: No!

Nick (With the beginning of a knowledge he cannot face): What are you two talking about?

George: I can kill him, Martha, if I want to.

Martha: HE IS OUR CHILD.

...

Martha: AND I HAVE KILLED HIM!

Martha: NO!

George: YES!

Nick (Very quietly): I think I understand this.

George: Good for you, buster.

Nick (Violently): GESUS CHRIST I THINK I UNDERSTAND THIS!

Martha (Great sadness and loss): You have no right ... you have no right at all.

George (Tenderly): I have the right, Martha. We never spoke of it; that's all. I could kill him any time I wanted to.

Martha: But why? Why?

George: You broke our rule, baby. You mentioned him ... you mentioned him to someone else. (Albee, 1963, p.236)

\section{CONCLUSION}

It is not love, it is not hatred; it is a love-hate relationship. It is a game they run and at the same time do not like to run. It is a power game that although they try to stop, it goes on and on and it also gets more complicated and the more the characters try to set themselves free, the more the noose tightens. It is a pathological interaction, the third party, Honey and especially Nick are entangled in. This is the time of revelation for Nick and Honey; the time they understand that they shouldn't have taken side with any of them since they have also been entangled, although it had nothing to do with them.

Getting out of the pathological game of Martha and George, Honey decides to have a child, a baby; Nick several times cries out that he understands this. They get out of the game, they leave George and Martha but the game continues for Martha and George and nothing from within can stop the game. Martha, who wrongly thought that she was the winner and manipulator of the game, is found herself deceived by George in their chess-like game. When George recites "Who's afraid of Virginia Woolf?" Martha cries out: "I ... am ... George ... I ... am" (Albee, 1963, p.242). "Martha admits that she is afraid of Virginia Woolf - a woman afflicted with a madness that drove her to suicide" 
(Cohn, 2006, p. 94), very much like Virginia Woolf, Martha is afflicted with George's deceits driving her to madness. The play ends with Martha's uncertainty about everything even about her feelings:

George: Are you all right?

Martha: Yes. No. (Albee, 1963, p.24)

The only remedy for stopping the game and the pathological quarrel between them is the death of one of the partners, George or Martha, otherwise even by the death of their son, and the absence of the third party, Nick and Honey, the game of power, the love-hate interaction pathologically continues. The paradoxical interaction, the love-hate relationship between Martha and George, and also the spiral perspectives are the cause of their pathological interaction from which there is no vent out for the characters. They are interacting as devils when put in each other's company and each of them thinks that he is able to read the mind of the other party and this causes a "vortex" or system of interlocking spiral perspectives in this play which leads to a pathological interaction, a game without end.

\section{REFERENCES}

[1] Albee, E. (1963). Who's Afraid of Virginia Woolf?. New York: Atheneum.

[2] Cohn, R. (2006). The Verbal Murders of Edward Albee. In B. Murphy and L. J. C. Cella (eds.), Twentieth Century American Drama. New York: Routledge, 82-97.

[3] Gilleman, L. (2008). Mind the Gap: Perception and Cognition in Harold Pinter's Confrontation Scenes. In F. Gillen \& S. Gal (eds.), The Pinter Review: Nobel Prize/Europe Theatre Prize Volume. Tampa, FL: U of Tampa P, 68-92.

[4] Laing, R. D. (2002). The Self and Others: Selected Works. London: Taylor \& Francis e-library.

[5] Laing, R. D. (1961). The Self and Others: Further Studies in Sanity and Madness. London: Tavistock Publications.

[6] Price, S. (2007). Fifteen-Love, Thirty-Love: Edward Albee. In D. Krasner (ed.), A Companion to Twentieth-Century American Drama. Malden: Blackwell Publishing, 247-262.

[7] Roudane, M. C. (2006). Thematic Unity in the Theatre of Edward Albee. In B. Murphy \& L. J. C. Cella (eds.), Twentieth Century American Drama. New York: Routledge, 106-111.

[8] Schechner, R. (2006). Who's Afraid of Edward Albee? In B. Murphy \& L. J. C. Cella (eds.), Twentieth Century American Drama. New York: Routledge, 75-78.

[9] Watzlawick, P., J. B. Bavelas, and D. D. Jackson. (1967). Pragmatics of Human Communication: A Study of Interactional Patterns, Pathologies, and Paradoxes. New York: W. W. Norton and Company.

[10] Zinman, T. (2008). Edward Albee. Michigan: The University of Michigan Press.

Samira Sasani (PhD., English Literature, Shiraz University) presently works as a full-time faculty member at the Department of Foreign Languages, as an assistant professor of English literature at Shiraz University, Shiraz, Iran. She has received her B. A. in English Literature from Shiraz University in 2006, her M. A. in English Literature from Shiraz University in 2008, and her Ph. D. in English Literature from Shiraz University in 2012. 